\title{
Pengaruh Harga, Merek dan Kualitas Pelayanan Terhadap Keputusan Menjadi Customer Tetap Jasa Pengiriman
}

\author{
Fatimah Pohan \\ Universitas Nahdlatul Ulama Sumatera Utara, Medan, Indonesia \\ Email: fatimahpohan1976@gmail.com \\ Submitted: 13 Februari 2021; Accepted: 15 Februari 2021; Published: 28 Februari 2021
}

\begin{abstract}
Abstrak-Sistem jual beli online sudah sangat banyak digunakan oleh banyak kalangan yang membuat semakin banyak pihak yang membutuhkan pihak ketiga sebagai pengantar dan perantara aman barang dari penjual sampai pembeli, tidak hanya jual beli online jarak dengan orang terdekat juga tidak menjadi hambatan lagi karena dapat berbagi dengan mengirimkan barang melalui jasa pengiriman sehingga usaha jasa pengiriman ini sangat banyak diminati untuk dibuka perusahaan-perusahaan startup sehingga banyak pesaing yang terjadi salah satunya pesaingan untuk mendapatkan Customer atau pelanggan tetap dengan berbagai cara dan strategi matang yang dilakukan demi mencapai tujuan perusahaan. Pada penelitian ini ingin melihat pengaruh harga, merek dan kualitas pelayanan sangat berhubungan erat dalam mendapatkan Customer tetap, Customer tetap haruslah didapatkan bahkan sangat perlu ditingkatkan jumlah Customer tetap yang berarti Customer tersebut akan selalu setia dan loyal kepada salah satu jasa pengiriman hal ini dapat meningkatkan nilai perusahaan dan meingkatkan keberlangsungan hidup perusahaan dalam mencapai tujuan perusahaannya, pada penelitian ini melihat seberapa berpengaruhnya antara masing-masing variabel.
\end{abstract}

Kata Kunci: Harga, Merek, Kualitas Pelayanan, SPSS

Abstract-The online buying and selling system has been very widely used by many groups which makes more and more parties need a third party as a safe delivery and intermediary for goods from the seller to the buyer, there is no buying and selling online, the distance from the closest person is also not an obstacle because it can only be sharing by sending goods through shipping services so that this shipping service business is very much in demand to open startup companies so that many competitors occur, one of which is competition to get customers or regular customers in various ways and mature strategies carried out to achieve company goals. In this study, we want to see the effect of price, brand and service quality which are closely related in getting regular customers, regular customers must be obtained even it is necessary to increase the number of regular customers, which means that the customer will always be loyal and loyal to one of the shipping services, this can increase value. companies and increasing the survival of the company in achieving its corporate goals, this study looks at whatever happens between each variable.

Keywords: Price, Brand, Service Quality, SPSS

\section{PENDAHULUAN}

Pertumbuhan ekonomi semakin bertumbuh berkembang dengan pesat salah satu dengan terus meningkatnya dunia pemasaran maupun dunia jual beli dalam negeri sampai luar negeri, setiap pertumbuhan ekonomi terjadi tidak lepas dari kemampuan dalam managemen masing-masing aspek pelaku ekonomi, dalam dunia jual beli saat ini sistem transaksi sudah sangat terbiasa melakukan secara digital atau biasa disebut dengan jual beli online, karena kemudahan dalam memilih barang yang sesuai dengan selera dan harga yang sesuai dengan perkiraan pembeli tanpa harus mendatangi took secara langsung dan sangat hemat terhada waktu dan dapat melakukannya dimana saja dan kapan saja dengan bantuan smartphone dan jaringan internet sudah dapat melakukan transaksi online, transaksi online tidak biasanya dapat dicapai dengan adanya pihak ketiga selain antara penjual dan pembeli masih ada perantara pengantar barang karena jual beli online membuat sesorang tidak hanya dapat melakukan transaksi lokal dalam daerah bahkan dapat belanja luar kota, provinsi maupun antar negara lain sehingga pihak ketiga yaitu penyedia jasa pengiriman barang sangatlah dibutuhkan keberadaaanya(Juanita, 2017).

Tingkat pelaku transaksi online hampir sebesar 90\% masyarakat Indonesia melakukan transaksi online selain sebagai pelaku pembeli rata-rata kemudahan akses internet ini membuat hampir seluruh pekerja memiliki pekerjaan sampingan maupun pekerjaan utama sebagai penghasil keuangan dengan cara menjadi penjual barang online juga, hal ini menyebabkan peluang maju dan berkembang pesatnya jasa pengiriman barang semakin tinggi dan mengakibatkan banyak perusahaan startup berlomba-lomba mencari peruntungan yang sama. Banyaknya perusahaan jasa pengiriman mengakibatkan banyak juga resiko bagi masing-masing perusahaan semakin maju dan berkembang sebuah perusahaan maka semakin tinggi juga tingkat reskio yang akan menghampiri seperti adanya pesaing(SHIELDSA WIJONO, 2012).

Dengan adanya jumlah pesaing dapat mengakibatkan sebuah perusahaan jasa pengiriman kekurangan pendapatan secara signifikan, adanya kekurangan pelanggan atau Customer sangat berdampak besar dan mengarah kepada kerugian besar sehingga perlu dilakukan pengawasan terhadap pengolahan resiko dengan melihat dan menganalisa aspek-aspek penyebab apa saja Customer memilih jasa pengiriman barang dan menjadi Customer tetap, semakin banyak Customer yang memilih menjadi Customer tetap suatu perusahan terhadap produk maka akan semakin banyak laba maupun benefit dari sebuah perushaan tersebut dan merupakan cita-cita yang dimiliki setiap perusahaan(Viterbo et al., 2020).

Perusahaan jasa pengirimnan menawarkan produk berupa layanan harga kamampuan waktu dalam jarak tempuh dan tanggung jawab atas resiko keamanan barang, tetapi dalam hal menanggulangi resiko sebuah perusahaan harus mengetahui dan memperhatikan terhadap resiko internal dan eksternal yang akan membuat jatuhnya sebuah perusahaan jasa pengiriman dengan menghilangnya minat Customer menjadi konusumen tetap diakibatkan Karena keputusan Customer terhadap minat terhadap perusahaan telah hilang karena adanya perusahaan pengganti yang dapat memenuhi 
keinginan masing-masing Customer bias saja dari aspek internal sendiri seperti harga, merek dan kualitas pelayanan dari perusahaan(Chavali \& Mohanraj, 2016).

Setiap perusahaan pasti ingin memiliki Customer yang tetap lagi bertambah kepercayaan terhadap perushaan sehingga selalu melakukan pengembangan dan strategi untuk mengetahui kesalahan apa saja yang harus diketahui untuk mengembangkan strategi dalam mempertahankan eksistensi perusahaan masing-masing, dalam penelitian ini dilakukan penelitingan dengan melihat pengaruh antara variable harga, merek dan kualitas pelayanan terhadap keputusan Customer(Phadermrod et al., 2019).

\section{METODOLOGI PENELITIAN}

Pada penelitian ini dilakukan beberapa tahapan dalam pengambilan data untuk mengetahui pendapat untuk tetap membuat arah laju penelitian ini lebih terarah, dengan adanya metodologi penelitian biasa disebut dengan analisis teoristis yaitu melakukan analisis terhadap setiap aspek pendukung dari peneitian ini.

\subsection{Pengumpulan Data}

Pengumpulan data dalam penelitian melakukan penyebaran dimana Kuesioner dilakukan dengan cara memberikan pertanyaan kepada Customer yang datang dengan beberapa pertanyaan yang menyangkut dengan harga, merek dan banyak pertanyaan juga yang menyangkut tentang kualitas pelayanan yang diberikan selama proses transaksi. Fungsi dari kuesioner ini adalah untuk menyaring dan mendapatkan data-data mutlak atau data primer dari subjek penelitian. Pengisian dilakukan secara langsung dengan kesadaran penuh dan bersungguh-sungguh dalam pengisian setiap pernyataan maupun pertanyaan yang terkait untuk melihat validasi sebuah data(Ismail et al., 2018).

Pengumpulan data juga menggunakan teknik dokumentasi dan studi pustaka berfungsi untuk melengkapi data yang diambil dari sumber-sumber terpecaya seperi jurnal, buku, web resmi yang dirangkum dalam bentuk dokumentasi untuk lebih membantu dalam penggambaran terhadap teknik maupun langkah apa saja yang ingin diketahui dalam sebuah penelitian.

\subsection{Harga}

Harga adalah sebutan untuk hal yang harus dibayar atau diberikan untuk mendapatkan suatu hal tertentu yang dibutuhkan, dalam pemasaran harga sangat berperan penting dalam mengatur segala aspek dan sangat mempengaruhi konsumen dalam menentukan keputusan terhadap suatu produk baik akan membeli sebuah produk maupun mengabaikan sebuah produk, harga juga sangat berpengaruh kepada peningkatan kinerja usaha dan pemasaran dan harga juga merupakan cara kompetisi pesaingan antara perusahaan satu dan perusahaan lain dengan sebuah harga dapat menjadi indicator terhadap nilai sebuah objek yang ditunjuk(AMILIA, 2017).

\subsection{Merek}

Merek merupakan tanda maupun penghantar seseorang mengenali sebuah objek, merek juga merupakan identitas dari sebuah perusahaan untuk menghasilkan value, merek itu sendiri terdiri dari warna, tulisan maupun icon yang memiliki arti tersendiri Karen setiap bentuk merek sebagai alat komunikasi antara perusahaan dan pelanggan dalam mengenal kualitas, harga, dan kepercayaan terhadap janji yang disediakan perusahaan melalui sebuah merek(AMILIA, 2017).

\subsection{Kualitas Pelayanan}

Kualitas pelayanan merupakan tampilan yang diberikan perusahaan berupa service dalam proses transaksi antara konsumen dan perusahaan, kualitas pelayanan mampu mempengaruhi rasa dan memberikan kepercayan customer untuk memegang janji dari sebuah perusahaan tentunya kualitas pelayanan sudah dirancang oleh pihak perusahaan sebagai stategi dalam menjalankan tujuan perusahaan secara langsung. Kualitas pelayanan dapat juga diartikan sebagai cara perusahaan menunjukan segala aktivitas untuk memberikan pemenuhan harapan yang ada pada Customers dan pelayanan ini dapat berupa kemudahan, etika, keramahtamahan, kemampuan dan pemenuhan janji terhadap kualitas dari sebuah produk(Weenas, 2013).

\subsection{Metode Analisis}

Pada penelitian ini menggunakan metode analisi berupa penggunaan tools atau alat berupa alat analisis statistika berupa SPSS yang telah dirilis oleh perusahaan IBM untuk melakukan perhitungan-perhitungan terkait, SPSS ini merupakan perangkat lunak yang sangat banyak digemari dan digunakan para peneliti pelaku ekonomi baik dalam analisis string menggunakan algoritma, analisis dengan data yang sangat besar dan sangat popular dengan sebutan software analisis data tingkat lanjut, sementara pada tahapan pengujian ini menggunakan beberapa tahapan pengujian seperti uji validasi dan realibilitasi instrument(Aren \& Nayman Hamamci, 2020).

Uji validasi bertujuan untuk dapan menggambarkan berapa tingkat akurasi terhadap penelitian dengan hasil semakin tinggi terhdap hasil pengujian menunjukan bahwasannya semakin akurasi tahapan dan tingkatan pengujian dan uji realibilitasi instrument sendiri merupakan tingkat kepercayaan terhadap penelitian yang akan diuji dan berhubungan kepada konsisten, kerendahan dan keselarasan(Hoffmann et al., 2013). 


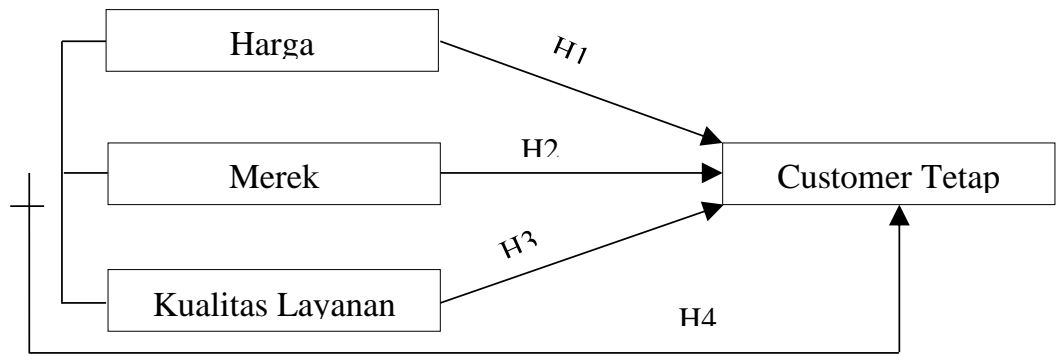

Gambar 1. kerangka pemikiran

\subsection{Uji Asumsi Klasik}

Pada uji regrei linear berganda digunakan pengujian asumsi klasik yang bertujuan memebuhi keseluruhan pencapaian data yang ingin diperoleh hasilnya, tujuan dari pengujian ini ialah untuk menghitung nilai variabel yang terlah ditentukan pada penelitian menggunakan pengujian asumsi klasik ini menggunakan pengujian Multikolenearitas yang bertujuan untuk mengetahui ada atau tidaknya kolerasi antara variabel dan pada pengujian ini menggunakan tools SPSS sebagai alat bantu analisis(Lie, 2009).

\subsection{Penelitian Terdahulu}

Sebuah penelitian tidak akan menjadi sebuah penelitian yang baik jika penelitian itu hanya berdasarkan pemikiran seseorang semata, sangat diperlukan melakukan peninjauan terhadap penelitian terdahulu untuk sebagai bahan tambahan Dan Wawasan Terhadap Penelitian-Penelitian Terkait Contoh Penelitian Terhadulu Seperti "Analisis Pengaruh Produk, Harga, Distribusi, Dan Promosi Terhadap Keputusan Pembelian Serta Implikasinya Pada Kepuasan Pelanggan", "Kualitas Produk, Harga, Promosi Dan Kualitas Pelayanan Pengaruhnya Terhadap Keputusan Pembelian Spring Bed Comforta" Kualitas Produk, Strategi Promosi Dan Harga Pengaruhnya Terhadap Keputusan Pembelian Kartu Simpati Telkomsel Di Kota Manado"(Weenas, 2013),(Saputri, 2016),(Hanafi et al., 2019)

\section{HASIL DAN PEMBAHASAN}

Peneilitian ini menggunakan teknik pengumpulan data dari konsumen yang dikumpulkan dalam sebuah kuesioner untuk melakukan pengujian berdasarkan parameter nilai yang disediakan terhadap beberapa variable pendukung yang telah ditentukan sebelumnya setiap pertanyaan diberikan jawaban berupa range antara 1-5 yang menunjukan tingkat dari pendapat masing-masing narasumber semakin tinggi angka range yang diberikan semakin menunjukan kualitas terhadap penilaian semakin membaik pula, dari hasil data analisa menggunakan SPSS.

\subsection{Uji Validitas Variabel}

Uji validitas dilakukan pada masing-masing variable untuk mengetahui valid sebuah data dikatakan valid jika instrument yang kita buat jika $\mathrm{R}$ hitung atau keseluruhan hasil lebih besar dari pada $\mathrm{R}$ tabel maka data tersebut dinyatakan valid dan data $r$ tabel dapat dilihat dari google tentang $r$ tabel contoh pada soal penelitian ini terdapat sebanyak 25 sampel dengan ketentuan melihat $r$ tabel adalah jumlah total respondensif-2 dan hasil yang di tentukan taraf signifikasinya adalah daerah 0.05 sehingga data yang menjadi strandar validitasi sebuah variable adalah $r$ tabel ke 23 makan yang digunakan pada $r$ tabel adalah 0,3961. sebagai berikut ini:

1. Validitas Variabel Harga

Tabel 1. Validitas Variabel Harga

\begin{tabular}{|c|c|c|c|c|c|c|}
\hline \multicolumn{7}{|c|}{ Correlations } \\
\hline & & $\mathrm{x} 1.1$ & $\mathrm{x} 1.2$ & $\mathrm{x} 1.3$ & $\mathrm{x} 1.4$ & total_x1 \\
\hline \multirow[t]{3}{*}{$\mathrm{x} 1.1$} & Pearson Correlation & 1 & .299 & .298 & .274 & $.738^{* *}$ \\
\hline & Sig. (2-tailed) & & .146 & .149 & .186 & .000 \\
\hline & $\mathrm{N}$ & 25 & 25 & 25 & 25 & 25 \\
\hline \multirow[t]{3}{*}{$\mathrm{x} 1.2$} & Pearson Correlation & .299 & 1 & .188 & -.170 & $.515^{* *}$ \\
\hline & Sig. (2-tailed) & .146 & & .368 & .417 & .008 \\
\hline & $\mathrm{N}$ & 25 & 25 & 25 & 25 & 25 \\
\hline \multirow[t]{3}{*}{$\mathrm{x} 1.3$} & Pearson Correlation & .298 & .188 & 1 & .190 & $.691^{* *}$ \\
\hline & Sig. (2-tailed) & .149 & .368 & & .362 & .000 \\
\hline & $\mathrm{N}$ & 25 & 25 & 25 & 25 & 25 \\
\hline \multirow[t]{3}{*}{ x1.4 } & Pearson Correlation & .274 & -.170 & .190 & 1 & $.536^{* *}$ \\
\hline & Sig. (2-tailed) & .186 & .417 & .362 & & .006 \\
\hline & $\mathrm{N}$ & 25 & 25 & 25 & 25 & 25 \\
\hline \multirow[t]{3}{*}{ total_x1 } & Pearson Correlation & $.738^{* *}$ & $.515^{* *}$ & $.691^{* *}$ & $.536^{* *}$ & 1 \\
\hline & Sig. (2-tailed) & .000 & .008 & .000 & .006 & \\
\hline & $\mathrm{N}$ & 25 & 25 & 25 & 25 & 25 \\
\hline
\end{tabular}


Pada hasil diatas diketahui data x1 total tidak ada yang dibawah ketentuan 0,3961 sehingga data dapat dikatakan valid dan lakukan pengjian validitasi variabel lain menggunakan SPSS.

2. Uji Validitasi Variabel Merek

Pada uji validitasi variable Marek pada instrument data terdapat hasil dari x2.1 dengan hasil 0,777 pada x2.2 memiliki hasil 0,768 pada x2.3 hasil yang didapatkan 0,639 dan hasil dari x2.4 sebanyak 0,732 sehingga data dinyatakan tidak ada dibawah 0,3961 dan berarti data dikatakan valid

3. Uji Validitasi Kualitas Pelayanan

Pada uji validitasi Kualitas Pelayanan terdapat hasil menggunakan tools SPSS pada x3.1 dengan hasil 0,756, pada x3.2 didapatkan hasil 0,839, pada x3.3 hasil yang ditemukan 0,833 dan pada x3.4 hasil 0,662 yang menyatakann keseluruhan data instrument valid.

4. Uji Validitasi Keputusan Konsumen Tetap

Uji validitas keputusan konsumen tetap didapatkan hasil pada y1.1 yaitu 0,871 dan y1.2 adalah 0,688, y1.3 adalah 0,901 dan y1.4 sebesar 0,901 data hasil terhadap keputusan konsumen juga dinyatakan valid

\subsection{Uji Reabilitas}

Digunakan untuk melihat konsistensi terhadap uji validitasi yang telah dilakukan tujuan dari melakukan pengujian validitas dan uji reabilitas ini berfungsi untuk mengetahui kualitas dari kuesioner danpada pengujian ini dapat dilakukan hanya jika sudah mengerjakan pengujian validitas dan pengujian ini dapat dilakukan bersama-sama tanpa memasukan total dari masing-masing variabel, setelah menggunakan aplikasi SPSS maka hasil yang didapatkan adalah:

Tabel 2. Uji reabilitas

\begin{tabular}{|c|c|}
\hline \multicolumn{2}{|c|}{ Reliability Statistics } \\
\hline Cronbach's & \\
\hline Alpha & $\mathrm{N}$ of Items \\
\hline .883 & 16 \\
\hline
\end{tabular}

Hasil yang didapatkan dari uji realibility ini sebesar 0,883 yang menyatakan bahwa data kuesioner sangat konsisten, realibel dan sangat layak untuk dilakukan pengujian dalam sebuah penelitianmenurut wiratna sujarweni tahun 2014, data kuesionel disebut reliabel jika data >0,6 dan hasil dari output sebesar 0,883 yang jelas data sangat reliabel.

\subsection{Uji Multikolinearitas}

uji ini merupakan bagian dari uji asumsi klasik dalam sebuah analisis regresi linear berganda dan pada penelitian ini dilakukan untuk melihat kejadian antara satu variabel dan varabel lain, pada penelitian ini disebut dengan variabel bebas atau variabel $\mathrm{X}$ dan melihat kolerasi yang tinggi dan pada penelitian menggunakan multikolinearias.

Tabel 3. Uji Multikolinearitas

\begin{tabular}{|c|c|c|c|c|c|c|c|c|}
\hline \multicolumn{9}{|c|}{ Coefficients $^{\mathbf{a}}$} \\
\hline \multirow[b]{2}{*}{ Model } & & \multicolumn{2}{|c|}{$\begin{array}{l}\text { Unstandardized } \\
\text { Coefficients }\end{array}$} & \multicolumn{2}{|l|}{$\begin{array}{l}\text { Coefficient } \\
\text { s }\end{array}$} & \multirow[b]{2}{*}{ Sig. } & \multicolumn{2}{|c|}{$\begin{array}{l}\text { Collinearity } \\
\text { Statistics }\end{array}$} \\
\hline & & $\mathrm{B}$ & Std. Error & Beta & $\mathrm{t}$ & & Tolerance & VIF \\
\hline \multirow[t]{4}{*}{1} & (Constant) & 5.689 & 3.008 & & 1.892 & .072 & & \\
\hline & Harga & -.361 & .380 & -.227 & -.951 & .353 & .268 & 3.730 \\
\hline & Merek & -.021 & .270 & -.016 & -.078 & .939 & .360 & 2.778 \\
\hline & $\begin{array}{l}\text { Kualitas_L } \\
\text { ayanan }\end{array}$ & 1.059 & .202 & .990 & 5.244 & .000 & .430 & 2.327 \\
\hline a. Dep & ent Variable & utusan & onsumenTeta & & & & & \\
\hline
\end{tabular}

Pada uji ini menggunakan dasar pengambilan keputusan dengan menggunakan nilai Tolerance dan Nilai VIF maka dapat ditarik dalam pengambilan keputusan pada uji ini dengan beberapa syarat yaitu

1. Jika nilai tolerance lebih besar dari pada $0,10(>0,10)$ berarti tidak ada terjadi gejala multikolinearias

2. jika nilai VIF lebih kecil dari pada $10,10(<10,0)$ maka artinya tidak terjadi gejala tersebut

dari hasil data coefficients pada data keterangan tabel Collinearity Statistics menunjukan kedua gejala tidak ada pada data kolerasi.

\subsection{Uji Analisis Regresi Berganda}

Penelitian ini bertujuan untuk melihat pengaruh terhadap variabel-variabel bebas dengan variabel terikat, variabel terikat merupakan variabel pendukung sementara variabel terikat itu sendiri merupakan tujuan dari penelitian terhadap dampak yang diterima dalam keterkaitan masing-masing bariabel, terdapat beberapa pengujian terdapat uji $\mathrm{T}$ yaitu untuk mengetahui perngaruh tersendiri terhadap variabel bebas dengan variabel terikat, selanjutnya dilcari uji $F$ yaitu bertujuan untuk mengetahui pengaruh keseluruhan variabel bebas atau variabel pendukung dengan variabel terikat atau variabel yang menjadi tujuan dan terakhir melihat koefisien diterminasi yaitu melihat persenan keseluruhan variabel bebas mempengaruhi variabel terikat. 
Tabel 4. Masukan Variabel Terkait

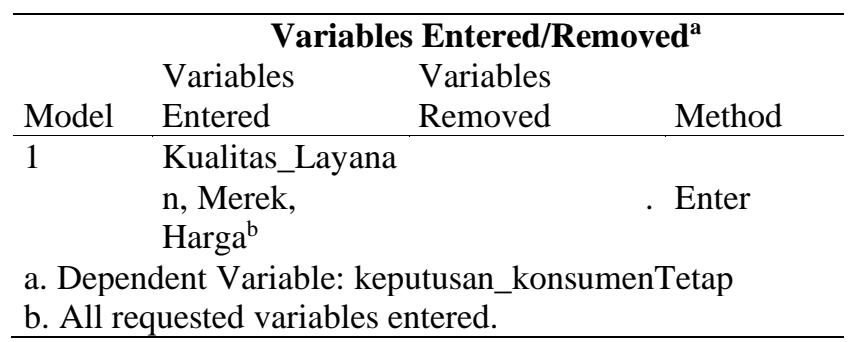

Pada table diatas data yang akan dimasukan berupa data variable X1, X2, X3 sebagai variable bebas atau masukan menuju variable Dependent tau variable terikat.

Table 5. Model Summary

\begin{tabular}{lcccr}
\hline & \multicolumn{4}{c}{ Model Summary } \\
Model & $\mathrm{R}$ & R Square & $\begin{array}{c}\text { Adjusted R } \\
\text { Square }\end{array}$ & Std. Error of the Estimate \\
\hline 1 & $.824^{\mathrm{a}}$ & .679 & \multicolumn{6}{c}{.633} & 2.733 \\
a. Predictors: (Constant), Kualitas_Layanan, Merek, Harga & \\
\hline
\end{tabular}

Pada tabel 5 merupakan tabel model summary merupakan tabel yang akan dibaca untuk melihat presentase dari nilai koefisien diterminasi atau yang disebut dengan persentase akhri pada pengujian.

Tabel 6. ANOVA

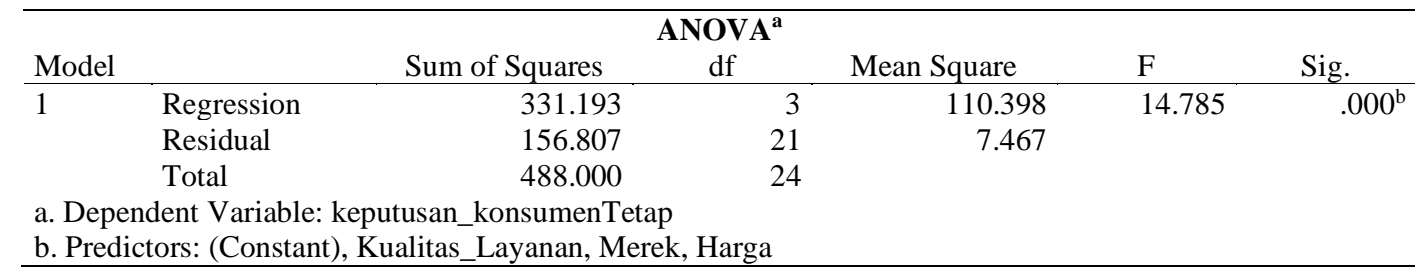

Tabel 6 memperlihatkan kita terhadap nilai dari fungsi F dimana akan dilakukan perhitungan akhir pada uji $\mathrm{F}$ dan fungsi f yang terkait.

Tabel 7. Coefficients

\begin{tabular}{|c|c|c|c|c|c|c|}
\hline \multicolumn{7}{|c|}{ Coefficients $^{a}$} \\
\hline \multirow{2}{*}{\multicolumn{2}{|c|}{ Model }} & \multicolumn{2}{|c|}{ Unstandardized Coefficients } & \multicolumn{3}{|l|}{$\begin{array}{l}\text { Standardized } \\
\text { Coefficients }\end{array}$} \\
\hline & & B & Std. Error & Beta & $\mathrm{t}$ & Sig. \\
\hline 1 & (Constant) & 5.689 & 3.008 & & 1.892 & .072 \\
\hline & Harga & -.361 & .380 & -.227 & -.951 & .353 \\
\hline & Merek & -.021 & .270 & -.016 & -.078 & .939 \\
\hline & Kualitas_Layanan & 1.059 & .202 & .990 & 5.244 & .000 \\
\hline & dent Variable: kepu & nsumenTetap & & & & \\
\hline
\end{tabular}

Pada tabel 7 terlihat tabel diatas merupakan hasil yang diperlihatkn pada uji $\mathrm{t}$ dan melakukan Uji $\mathrm{T}$ terakhir untuk mengetahui hubungan pengaruh antara satu variable dengan variable lainnya, sebelum pada perhitungan akhir dilakukan perhitungan sebagai batasan terhadap hasil pada uji t dan uji F sebagai berikut ini:

Nilai uji t diperoleh dari

$\mathrm{t}$ tabel $=\mathrm{t}(\mathrm{a} / 2 ; \mathrm{n}-\mathrm{k}-1)$

$=\mathrm{t}(0,05 / 2 ; 25-3-1)$

$=\mathrm{t}(0,025 ; 21)$

$\mathrm{t}$ tabel harus dilihat pada distribusi tabel nilai $\mathrm{t}$ dengan melihat pada nilai 0,025 pada baris ke 21 maka hasil $\mathrm{t}$ tabel adalah $=2,080$

Nilai Uji F diperoleh dari

$\mathrm{F}$ tabel $=\mathrm{f}(\mathrm{k} ; \mathrm{n}-\mathrm{k})=\mathrm{F}(3 ; 22)=3,05$

F tabel dilihat pada kolom 3 pada baris ke 22 diperoleh angka 3,05

\section{KESIMPULAN}

Pada data diatas dapat ditarik kesimpulan bahwasannya terjadi beberapa hal dalam pengujian dalam bentuk hipotesis dan pada pengambilan keputusan dilihat dari nilai sig yang dilakukan untuk melihat pengaruh variabel pertama yaitu

1. Hipotesis pertama $(\mathrm{H} 1)$ 
variabel harga $(X 1)$ sebesar 0,72 >0,05 dan pada nilai t yang telah dihitung sehingga 1,892 >t tabel yaitu 2,080 yang berarti harga sangat berpengaruh besar terhadap keputusan menjadi konsumen tetap.

2. Hipotesis kedua (H2)

Variabel kedua yaitu bariabel hipotesis kedua adalah merek dapat dilakukan dengan cara yang pertama tampak jelas sebesar $0,939>0,05$ dan pada nilai $t$ yang telah dihitung sehingga $-0,951>t$ tabel yaitu 2,080 berarti merek tidak berpengaruh terlalu signifikan terhadap ketputusan menjadi konsumen tetap yang menunjukan hipotesis ke dua dinyatakan sebagai hipotesis yang ditolak

3. Hipotesis ketiga $(\mathrm{H} 3)$

Hipotesis ke tiga yaitu variabel kualitas layanan dapat dilihat sebesar $0,000<0,05$ dan pada nilai t yang telah dihitung sehingga 5,244 $>\mathrm{t}$ tabel yaitu 2,080 sangat berpengaruh dan diterima dalam pengambilan keputusan konsumen menjadi konsumen tetap sebuah perusahaan.

4. Hipotesis empat (H4)

Pada pengujian ini yang diperhatikan adalah anova yang berhubungan dengan uji $\mathrm{F}$ diketahui nilai yang signifikansi terhadap pengaruh masing-masing variabel baik variabel harga (X1), Merek (X2), Kualitas Pelayanan (X3) terhadap keputusan menjadi konsumen tetap (Y) adalah sig $0,000<0,05$ dan pada uji $\mathrm{F}$ hitungan 14,785 $>3,05$ berarti secara keseluruhan sangat berpengaruh terhadap keseluruhan Variabel dan diterima dan terdapat pengaruh secara simultan terhadap keputusan menjadi konsumen tetap (Y)

5. Nilai persentase atau nilai koefisien

Nilai koefisien dapat dilihat pada model summary yaitu pengaruh seluruh variabel terhadap Y sebesar 6,79\%

\section{DAFTAR PUSTAKA}

AMILIA, S. (2017). Pengaruh Citra Merek, Harga, dan Kualitas Produk terhadap Keputusan Pembelian Handphone Merek Xiaomi di Kota Langsa. Jurnal Manajemen Dan Keuangan Unsam, 6(1), 660-669.

Aren, S., \& Nayman Hamamci, H. (2020). Relationship between risk aversion, risky investment intention, investment choices: Impact of personality traits and emotion. Kybernetes, 49(11), 2651-2682. https://doi.org/10.1108/K-07-2019-0455

Chavali, K., \& Mohanraj, M. P. (2016). Impact of demographic variables and risk tolerance on investment decisions: An empirical analysis. International Journal of Economics and Financial Issues, 6(1), 169-175.

Hanafi, I., Hubeis, A. V. S., \& Raharja, S. (2019). Strategi Peningkatan Daya Saing Produk Suku Cadang Otomotif dan Elektonik Berbahan Karet di PT BesQ Sarana Abadi. MANAJEMEN IKM: Jurnal Manajemen Pengembangan Industri Kecil Menengah, 13(2), 167. https://doi.org/10.29244/mikm.13.2.167-174

Hoffmann, C., Spiegl, U. J. A., Hauck, S., Bühren, V., \& Gonschorek, O. (2013). Die ventrale Spondylodese beim älteren Patienten Overtreatment oder sinnvolle Therapieoption? Zeitschrift Fur Orthopadie Und Unfallchirurgie, 151(3), $257-263$. https://doi.org/10.1055/s-0032-1328522

Ismail, I., Hasan, H., \& Musdalifah, M. (2018). Pengembangan Kompetensi Mahasiswa Melalui Efektivitas Program Magang Kependidikan. Edumaspul - Jurnal Pendidikan, 2(1), 124-132. https://doi.org/10.33487/edumaspul.v2i1.48

Juanita, S. (2017). Analisa Strategi Bisnis Penjualan Online. Konferensi Nasional ICT-M Politeknik Telkom, 254-260. http://journals.telkomuniversity.ac.id/knip/article/view/557

Lie, L. (2009). Penggunaan MRA dengan Spss untuk Menguji Pengaruh Variabel Moderating terhadap Hubungan antara Variabel Independen dan Variabel Dependen. Jurnal Teknologi Informasi DINAMIK, XIV(2), 90-97. https://www.unisbank.ac.id/ojs/index.php/fti1/article/view/95/90

Phadermrod, B., Crowder, R. M., \& Wills, G. B. (2019). Importance-Performance Analysis based SWOT analysis. International Journal of Information Management, 44, 194-203. https://doi.org/10.1016/j.ijinfomgt.2016.03.009

Saputri, M. E. (2016). Pengaruh Perilaku Konsumen Terhadap Pembelian Online Produk Fashion Pada Zalora Indonesia the Effect of Consumer Behavior Toward the Online Purchase of Fashion Product of Zalora Indonesia. Sosioteknologi, 15(2), 291-297.

SHIELDSA WIJONO, V. (2012). Dampak E-commerce Terhadap Pengendalian Internal Dan Proses Audit. Berkala Ilmiah Mahasiswa Akuntansi Widya Mandala, 1(2), 96-100.

Viterbo, L. M. F., Costa, A. S., Vidal, D. G., \& Dinis, M. A. P. (2020). Workers' healthcare assistance model (WHAM): Development, validation, and assessment of sustainable return on investment (S-ROI). International Journal of Environmental Research and Public Health, 17(9). https://doi.org/10.3390/ijerph17093143

Weenas, J. (2013). Kualitas Produk, Harga, Promosi Dan Kualitas Pelayanan Pengaruhnya Terhadap Keputusan Pembelian Spring Bed Comforta. Jurnal Riset Ekonomi, Manajemen, Bisnis Dan Akuntansi, 1(4), 607-618. https://doi.org/10.35794/emba.v1i4.2741 